\title{
The Progression of the Soviet Heroine in Film
}

\section{Julie $\mathrm{Vu}$}

Heroines in Soviet films adapted to conform to changing political and social views throughout the twentieth century. Oksana Bulgakova's observation of the metamorphoses of Soviet heroines marks the decline and peaks of complexity in their characters through each progressing year. There are two major historical periods which precipitated the evolving portrayal of female protagonists in cinema: the Thaw and Glasnost. The films The Cranes Are Flying (1957) and Little Vera (1988) establish two specific breakthroughs: they set the precedent for independent, complex heroines who defy the communist condemnation of the "individualist" mindset while also portraying the feminist struggles of their decades.

The paradigm of the Soviet heroine in film evolved dramatically throughout the twentieth century. During this era, female protagonists took on new looks, new attitudes, and new relations to male characters. Films such as The Cranes Are Flying, released in 1957 during "the Thaw," and Little Vera, released during the height of "Glasnost" in 1988, are prime examples of female protagonists who reflected the struggles and successes of Soviet women with increasing depth and complexity. Once merely pretty faces for the silver screen and faithful supporters of their male counterparts, Soviet heroines grew to project a strong sense of individualism and reveal their private lives for all to see. They developed from shallow characters heavily intertwined with communist ideology to unique individuals that struggle but also manage to achieve their goals with the limited privileges they have.

The appearances, attitudes, and functions of the Soviet heroine in film constantly evolved to reflect new social contexts brought upon by politics of war and revolution. Oksana Bulgakova refers to the women of the 1910s film era as "Queens of the Screen," who are also known as femme fatales (Bulgakova 149). They usually have humble beginnings as they start out as working class citizens and, by a twist of fate, somehow fall into a bourgeois life of luxury at the cost of "suffering, illness, and death" (Bulgakova 150). Films of this era are considered pre-revolutionary, revolving around tales of "seduction and temptation" with some of the common tropes involving romantic affairs (Bulgakova 150). It is important to 
note that women of this decade are not portrayed on screen as complex characters. Their lives entirely revolve around romantic affairs, and they are victims of their own vices. These female protagonists almost always suffer the same tragic ending often culminating in their deaths (Bulgakova 150). An example of this trope in film is the young countess from Queen of Spades (1916). The young countess is a noble woman that likes to gamble and in the end is killed by the protagonist of the film seemingly paying the ultimate price for her vices. Overall, the films of this decade served as warnings of the dangers that come with luxury and vice.

Faceless women of the masses wiped free of anything that set them apart as individuals, also known as "the Anti-Stars," would mark the Avant-garde era of the 1920s (Bulgakova 152). Dziga Vertov's Man with a Movie Camera (1929) exemplifies the lack of individuality in the films of the 1920s because it does not focus on a single character but rather the proletarian masses as a whole. Simple and beautiful women, free from any flaws, characterized the 1930s. The significance of film heroines is exceedingly reduced in the 1940s during the period of the Second World War, in which their roles are reduced to "dazzling blondes" in musical comedies and as young wives of soldiers who are expected to dutifully wait for the return of their husbands (Bulgakova 162). The exception for this trope would be Sergei Eisenstein's controversial film, Ivan the Terrible (1944), since the film is neither a musical comedy nor war film but rather a historical portrayal of one of Russia's infamous tsars. The tsarina does, however, conform to the 1940s heroine trope in that she is a virtuous and dutiful wife to the tsar for the entirety of the film and contains little to no complexity in her character. She possesses no flaws and her only aspiration is to support the tsar. The jump from the 1910s to the 1940s is significant in that individualism seems to be eradicated from film, and the role of women has been reduced to that of a one-dimensional supporting character. On-screen heroines had abandoned whatever essence of individualism and sensual allure they had in the 1910s. This trend, however, experienced a stunning reversal in the 1950s.

The 1957 film The Cranes Are Flying and its female protagonist Veronika marks the Soviet Union's transition into the era of the Thaw, which promised a series of progressive changes for women, film, and a new generation of disheartened citizens detrimentally affected by war. On March 6, 1953, Joseph Stalin's death set off a cataclysm of events ushering in a new era that would come to be known as the Thaw. Natasha Kolchevska defines the Thaw as "often mentioned in connection with Khrushchev's liberalization policies which was in itself a problematic and unstable phenomenon" (Kolchevska 114). However, some of Khrushchev's policies proved to be beneficial to women. For instance, women's education improved, their achievements were "increasingly recognized," some restrictive policies placed on women during Stalin's reign, including abortion, were lifted, and they were granted longer maternity leaves (Kolchevska 115). The "surge of interest in the status of women" was due to the loss of millions of men during the Second World War which skewed the country's demographics, resulting in a largely disproportionate population ratio of fifty-five women to forty-five men (Kolchevska 115). The loss of so many men meant that women had to play a crucial role as "major contributors to the country's reconstruction effort" while also meeting the demands of their homes and workplaces (Kolchevska 115). However, the improvement of women's circumstances were limited. Despite the reality that women had become the supportive backbone of Soviet society, "there [was] also a widespread tendency to denigrate them" (Kolchevska 115).

In The Cranes Are Flying, Veronika's rape and marriage to her rapist, Mark, is arguably 
one of the most controversial topics of the film. Her situation either draws sympathy from the audience or condemnation. Nevertheless, the film managed to do something no other film before it had succeeded in doing. It shone a light on the trope of "the faithless fiancée" to reveal a hidden reality that many women experience but are too afraid to discuss for fear of scorn. The Cranes Are Flying shows Veronika as a victim deserving of sympathy while also conveying diverse reactions towards her rape. The most prevalent reaction is scorn from both men and women, which further alienates her in her plight. According to Josephine Woll, this judgement as well as the audience's judgement is a direct result of the film's "refusal" to judge her (Woll 74). Veronika represents a generation of silent women who are unrightfully judged because of their sexual assault, but she also represented the birth of a new kind of heroine that would define films of the 1950s and make way for more independent women of future decades. She is the paradoxical "unremarkable heroine." She is unremarkable in appearance with her ordinary demeanor but possesses a remarkable inner strength and selflessness despite her unfavorable circumstances. She has a bleak view of the world, similar to the dreary perspective of a returning soldier, and possesses a greater deal of complexity when compared to the paradigms of previous decades. Anthony Anemone elaborates on Veronika's complexity, saying, "Veronika [was] instantly recognized by millions of Soviet women who [needed] a better reason than the one provided by official communist ideology to continue to live after the catastrophic losses of the war" (Rojavin 16). Josephine Woll's opinion on Veronika also supports this. She "does not embody civic virtues" and is not a "beacon of fidelity" nor "simple, loving, and modest" as female heroines were in the past (Woll 74-75). Veronika is complex because, despite being surrounded by ideology, she is able to think for herself. She is not the ideal communist woman but rather a realistic portrayal of a woman devastated by war who also desperately holds onto her hope despite all that has happened to her. She aims to persevere with all the limitations of being a woman scorned. Veronika is also one of the first heroines who shines as an individual and maintains her private life. Anemone notes that "one of the most shocking aspects of the movie is that individualist' behavior that [had] routinely been condemned in Soviet culture as selfish and philistine is now presented as natural, obvious and absolutely modern" (Rojavin 15). It is evident that The Cranes Are Flying made significant breakthroughs, especially for Soviet citizens exhausted from surviving two World Wars. By putting the "emotional needs of the individual" before that of society's, the film also motivates the audience to acknowledge their own needs and heal (Rojavin 17). Veronika is heralded as a heroine who revolutionized film, and she paved the path for future heroines as well.

Vasili Pichul's Little Vera is an example of how Soviet film heroines evolved in the 1980s. Ever since The Cranes Are Flying set the individualist precedent for future films, each following decade continued to develop their heroines into more complicated characters. Heroines of the 1960s finally get to experience a "prolonged" childhood due to the stabilization of Soviet society (Bulgakova 169). Not only are they able to participate in recreational activities due to less restrictive rules, but they are unique in that they are allowed to "make mistakes" (Bulgakova 168). Another decade later, the heroines of the 1970s are commonly known as the "working women." They were born from the death of the Thaw-the same era that revolutionized heroines of cinema by granting them individuality-and entered a new era of literary prose, "the era of analysing changes which had or had not happened" (Bulgakova 172). The heroines of the 1970s are much older and are often focused on building their 
careers. Heroines of this decade faced the common conundrum of having to choose success over love. Audiences consider these heroines to be strong, but perhaps less happy than other, less successful female characters in film. Vera, of Little Vera, is a heroine of the 1980s who is born from both of these preceding decades. Like the heroines of the 1960s, she is a teenager, yet she is unaware of the meaning of success, differentiating her from the heroines of the 1970s. Vera represents a lost generation of adolescents that would come to define the Glasnost era of the 1980s.

The new open environment of the 1980s allowed for film to touch upon heavy societal issues such as domestic abuse, alcoholism, pop culture, sex, and teen angst. In the film, one of Vera's major inner conflicts is that she feels stuck. According to Andrew Horton, there are not a lot of "alternatives to the roles laid out for her" similar to many teens of her time (Horton 19). Neither the life of a housewife nor the pursuit of higher education interest Vera, which gives reason to her frustration towards life. She is lost, has no passion towards future goals or a career, and has an unstable relationship with her family and her lover. Horton points out that Vera's "conflict in roles and values" acts as friction between her and her parents (Horton 20). She often feels like she must choose between her roles as daughter and wife, as in the scene when the police interrogate her about how her fiancée Sergei was stabbed. If she confesses the truth, she betrays her father and corrupts her role as the dutiful daughter. If she lies, then she corrupts her role as a loyal bride to Sergei. Horton even argues that at times Vera must play the role of a wife to her father:

Because of the distance her mother places between her husband and Vera, the daughter must also play the role of both wife and mother to her father. Thus while the father urges Vera to "cherish her youth," Vera is, in fact, the one who takes his complaints about his heart trouble seriously and who then undresses him and tucks him in bed early in the film. (Horton 20)

The result of this conflict shows a vast generational difference between the youth of the $80 \mathrm{~s}$ and the generations that came before, evident by the film's overall apathetic mood and its astonishingly accurate reflection of the Soviet Union's new reality. In Pichul's own words, "[t]he film is an attempt to come close to the abyss of our life today. Actually our real life is even darker, and yet I remain an optimist. Making a film is an exercise in hope" (Horton 21). The death of Vera's father is a metaphorical message about the inevitability of change. Vera's father represents the older generation with their outdated values and their burdening issues. His alcoholism and outdated morals held her back, which is why his death is necessary in order for Vera, the youth, to grow and find purpose in her life. It can be said that Little Vera is revolutionary in that it shows how "far contemporary Soviet cinema has now been allowed to move from the false enthusiasms and wooden idealism of Socialist Realism in its most rigid form" (Horton 21). At this point in Soviet film, heroines were no longer expected to fit socialist ideals nor embody virtues but reflected the real world with all its flaws and truths.

Veronika of The Cranes Are Flying became the first complex female heroine in Soviet cinema by representing silent women traumatized by sexual assault. In a way, she is the first "real" woman of cinema and breaks free from the traditional paradigm formed by communist ideals. She is also the first heroine to have a personal life and a strong sense of individualism, and her inspiring story of love and hardship stirred much needed discussion and healing for a 
generation of Soviets torn apart by war. Veronika paved the path for future heroines to grow and develop as unique individuals. Vera of Little Vera is a blend of the heroine tropes from both the 1960s and the 1980s. Misguided by the outdated values of her parents' older generation and unsure about the meaning of success, Vera represents many adolescents of the Glasnost era. Her strained relationships between herself and her parents and her lover resembles the generational gap between the older and new generation. Disagreements on the extent of filial piety and the value of education and careers result in a sense of lostness that will define the 1980s. Little Vera, when compared to the beginning of Soviet cinema, represents how far heroines had grown and changed in a way filmmakers of the 1910s never thought possible. From sinful femme fatales to faceless women of the masses, Soviet heroines managed to earn a sense of individuality and utilize their strength in order to fight for what they want. They were no longer bound to supporting roles of faithful wives but rose to become protagonists with agency and break free from the frigid molds of communist ideology. As a result, these heroines are able to inspire audiences and evoke sympathy without a mask of perfection. 


\section{References}

Bulgakova, Oksana. "The Hydra of the Soviet Cinema: The Metamorphoses of the Soviet Film Heroine." Red Women on the Silver Screen, edited by Lynne Attwood, Pandora, 1983, pp. 149-174.

Eisenstein, Sergei, director. Ivan the Terrible. Mosfilm, 1944.

Horton, Andrew. Film Quarterly, vol. 42, no. 4, 1989, pp. 18-21. JSTOR, www.jstor.org/ stable/1212823.

Kalatozov, Mikhail, director. The Cranes Are Flying. Warner Brothers, 1957.

Kolchevska, Natasha. "Angels in the Home and at Work: Russian Women in the Khrushchev Years." Women's Studies Quarterly, vol. 33, no. 3/4, 2005, pp. 114-137. JSTOR, www.jstor.org/ stable/40004421.

Pichul, Vasili, director. Little Vera. International Film Exchange Ltd., 1988.

Protazanov, Yakov, director. The Queen of Spades. 1915.

Rojavin, Marina, and Tim Harte. Women in Soviet Film: the Thaw and Post-Thaw Periods. London: Routledge, 2018. Print.

Vertov, Dziga, director. Man with a Movie Camera. VUFKU, 1929.

Woll, Josephine. Real Images: Soviet Cinema and the Thaw. London: I. B. Tauris, 2000. Print. 